\title{
Impact of Sand Harvesting on Education of Pupils in Public Primary Schools in Kathiani Division, Kathiani District, Machakos County, Kenya
}

\author{
Ms. Mutiso Veronicah Nthambi ${ }^{1}$, Prof. John Aluko Orodho ${ }^{2}$, \\ ${ }^{I}$ Doctorate student, Department of Educational Management, Policy and Curriculum Studies, School of \\ Education, Kenyatta University, Kenya \\ ${ }^{2}$ Associate Professor of Education and Research, Department of Educational Management, Policy and \\ Curriculum Studies, School of Education, Kenyatta University, Kenya
}

\begin{abstract}
The gist of this study was to investigate the impact of sand harvesting on education of pupils in public primary schools in Kathiani Division, Machakos County, Kenya. The study was premised on Horace Mann Classical Liberal Theory of Equal Opportunity which asserts that each person is born with a given amount of capacity, which to a large extent is inherited and cannot be substantially changed. A survey research design was adopted. Stratified sampling technique was applied to select 10 headteachers, 10 class teachers, 80 pupils, 2 local administration officers and 2 education officers, yielding a sample size of 104 subjects to participate in the study. Data collection instruments were questionnaires and interview guides. A pilot study was conducted to determine the validity and reliability of questionnaires. Data were analyzed mainly through use of descriptive statistics. The findings were that pupils were highly involved in sand harvesting activities that took place early in the morning before school, during school hours, evening, at night and over the weekends, leading to extreme exhaustion of pupils and lack of concentration in school activities. It was concluded that sand harvesting negatively influenced the education of pupils in terms of school attendance, indiscipline as well as dismal academic performance in national examinations. It was recommended that the government and other stakeholder should regulate sand harvesting activities and provide bursaries to the needy pupils to enhance pupils' access, retention and performance in primary school education in Kathiani Division, Machakos County Kenya. [244 words]
\end{abstract}

Key Words: Public primary schools, child labour, under-age children, sand harvesting, dropout rate, dismal academic performance, Kathiani Division, Machakos County, Kenya.

\section{Background to the Study}

\section{Introduction}

The central argument advanced in this paper is that since education is a basic human right recognized since adoption of the Universal Declaration of Human rights in 1948's and the commitment of the government of Kenya to join other international nations in 1990 to institutionalize Education for All (EFA) goal for Education for all children by 2015 particularly girls, those in difficult circumstances and those belonging to ethnic minorities (EFA Assessment Report, 2000), the emerging wastage in institutions of learning cannot be entertained by any nation. The International Labour Organization (2002) has blamed the poor participation in education to child labour since children who are working full time cannot go to school. In addition, the academic achievement of children who combine work and school is often compromised (Orodho, 2014).

The above negative trend is taking place against the background that the Republic of Kenya has set educational targets to be met by 2015 ( Republic of Kenya, 2012a,2012b; Republic of Kenya/UNESCO,2012). Total primary school enrolment is expected to grow at a stable rate during the period from 2010 to 2015 following the stabilization of the impact of FPE which began in 2003(Republic of Kenya, 2012a, 2012b). Enrolment in public primary schools is set to increase from about 8 million pupils in 2009 to 9.2 million in 2012 and 10.5 million by 2015. Total primary school enrolment (public and private) will increase from 9 million pupils in 2009 to 10 million in 2012 and 11.5 million by 2015 ( Republic of Kenya/UNESCO,2012).

Nonetheless, literature from developing countries, particularly from sub-Saharan Africa, indicate that things are not rosy as there is a strong tendency for school-age children to drop out of school at a tender age and enter into full-time employment ( Orodho,2013). According to the United Nations (2013), Sub-Saharan Africa has a large number of working children. The United Nations Children's Emergency Fund (UNICEF) specifically estimates that approximately $37 \%$ of children 5 to 14 years are actively involved in the labour market (UNICEF, 2007). The proportion of children working has continued to rise in the region. Child labour 
participation rates are highest in East Africa, followed by Central Africa and West Africa. Child labour is characterized by low wages, long hours, and in many cases, physical and sexual abuse (Admassie, 2002; Bass, 2004). UNICEF (2007) records that 75 million children in Africa were not in school in 2005 -2006 period and as many as 90 million children were without access to education. Asia is second with 21 percent followed by Latin America with 17 percent. In Africa, Mali has the highest percentage of working children with 54.4 percent, Burkina Faso with 51.1 percent, Burundi 49 percent, Uganda 45.3 percent and Niger 45.2 percent while Kenya ranks sixth with 41.3 percent.

The above statistical evidence regarding the wide prevalence and the negative impact of child labour on education notwithstanding, the concept of child labour remains vaguely conceptualized in most African societies. As a consequence of the lack of understanding of the concept and consequences of child labour among Kenyan pastoralists and hunter-gatherers, the contribution of child labour and its impact on education still remains "invisible" in national records (Orodho, 2014). The contribution of PEN (2009) in this thorny debate throws a spanner in the wax by revealing that sand harvesting business is booming due to the growing demand in construction industry, as a result; streams around Machakos, Kangundo, Kathiani, and Mwala are badly affected and the damage done has serious implication on the development of the region. School going children are forced to trek long distances in search of water for domestic use and their livestock at the expense of educational endevours. This could be a major cause of absenteeism and gradual school dropout in the area. It is against this backdrop that this study was conceived in an attempt to examine the impact of sand harvesting on education in Kathiani Division, Kathiani District, and Machakos County, Kenya.

\section{Concept of child Labour}

\section{Review of Related Literature}

There is a growing body of knowledge generated by researchers, educationists and international organizations on child labour.Amma, Baghdellah, Kiondo, Madhi, Mwandayi and Soko (2000) have tried specifically to look at child work in a more detailed way. To them child work covers tasks and activities that are undertaken by children to assist their parents. In particular, such jobs as cooking, washing dishes, weeding, planting, harvesting crops. Child work is therefore taken and viewed as part of the upbringing process. However, the meaning of child labour would appear to deviate from that of child work. According to ILO Convention, child labour is as stipulated hereunder: "Children prematurely leading adult lives, normally working long hours for low wages under conditions damaging to their health and to their physical and mental development, sometimes separated from their families, frequently deprived of meaningful educational training opportunities that could open up for them a better future (ILO/IPEC, 2001). This can be evidenced by Tungesvik (2000) whose findings indicate that about $61 \%$ of the children who labour are found in Asia, while $32 \%$ live in Africa and 7\% in Latin-America. Findings by ILO/IPEC Tanzania find support from the study by Masudi, Ishumi and Sambo (2001). The study found economic hardships at household level as the possible explanation underlying child labour in different parts of the country. In search for survival many children find their way into labour markets, which are actually detrimental and dangerous to their wellbeing. To this end, child labour has been continuously depriving children their rights to a number of opportunities including social services such as basic education. This finds support from the findings by Tungesvik (2000) which indicate that working children contribute about $40 \%$ of the household income that is geared to basic food items. Amma et al (2000) found, that in Kenya children were regarded as a source of livelihood for poor families.

Kaunga (2008) records that the 1998/99 child labour Report estimates that there are about 1.9 million child laborers in Kenya of whom $34 \%$ are in commercial agriculture and fisheries, and $23.6 \%$ in subsistence agriculture and $17.9 \%$ in the domestic sector. The scenario and circumstances in which child labour happens has changed leading to the demand by world nations to interrogate and define different notions or facets of child labour. Kaunga (2008) notes that there are now three accepted facets of child labour: child labour, child work and the Worst Forms of Child Labour. Child work is work done by children for purposes of socialization and normal development under supervision as long as it does not deprive them of their education and other rights.

Child labour is generally defined as work undertaken by children in the age group of 5-17 that prevents them from attending school and inhibits their general growth and/or development. The worst forms of child labour is labour which takes the form of slavery or bondage, prostitution or pornographic performance, drug trafficking or work which is likely to harm the health, safety or morals of the child (Kaunga, 2008). Generally, the legal and policy environment for enabling children to access and advance their rights has been improved by a number of high-level policies and actions by the Government of Kenya. These include the recent enactment of the Children Act (2001). The Act dictates compulsory education for all children. This has been strengthened by the pronouncement for free primary education in 2003. However, there is no comprehensive strategy to address the question of relevance of the curriculum and the entire education system to indigenous people's lifestyles. This has to a large extent contributed to low level of participation by indigenous children in the formal education and will continue to hinder their participation and retention in the formal education system. 
Indigenous child laborers are not, necessarily, benefiting from the free education policy, as the mainstream thinking and policy makers at the national level otherwise assume (Kaunga, 2008) According to Kaunga (2008), the phenomenon of child labour is not new in Kenya and the world over.

\section{Sand Harvesting and School Participation}

A major factor in the non-participation of children in schooling was found to be the need to prioritize educational investment in a few children, with the subsequent earnings of those not enrolled in school contributing to the household finances. But even for those children enrolled in school, their frequent failure to complete primary education was due to an inability of the children successfully to combine income generation, partly to finance their education, with that of school attendance. According to Carron and Chau (1996), there were two specific factors, which make school attendance irregular in China, Guinea, and Mexico. The factors included children having to help with work inside and away from the house and health problems among pupils, all of which are attributable to poor living conditions within the households.

Lanjouw and Feder (2002), point out that due to social and economic changes over the past 20 years, students have been forced to rethink the value of pursuing education as there are likely to be future disadvantages for students who do not maximize their educational opportunities. Edmonds (2003) found that boys who are more likely to be 'at risk' of early school leaving demonstrated low school achievement, live in rural or remote areas with a low socio-economic status. The costs of dropping out of high school can have a profound effect on a young person's life. The relative earnings of high school dropouts are lower than for those students who complete high school and/or college. Similarly, high school dropouts experience more unemployment during their work careers. Young women who drop out of high school are more likely to become pregnant at young ages and more likely to become single parents (Shafique, 2007). Despite efforts by the Government and NGOs to address primary education there are problems which still persist, and consequently deny some children their basic right to education in some areas/ countries in Africa.URT (2000) reveals that in Africa, $22.2 \%$ of children liable to go to school have not been enrolled, and 34\% of the enrolled drop out before completing primary schooling. Likewise, findings by the World Bank (2007) indicate that in Tanzania, although entry rates in primary schools are relatively high, survival rates at the end of the cycle are low. Drop-out is one of the underlying problems that face primary schools. Children also take an average of 9.4 years to finish primary education instead of seven years. Failure to complete primary education is attributed to dropouts and repetition, especially at standard four and only 50\% manage to complete grade 7. Similarly, Okojie, and Okpokunu (1996), report that in Nigeria school children get engaged in independent work in order to earn money. A number of other recent studies by Kanbargi and Kulkarni (1991), Grootaert and Patrinos (1998), and Nielsen (1998) have looked at the relationship between child work and schooling. However, of these, only Kanbargi and Kulkarni (1991) draw any inferences about the effect of work on schooling, concluding that children in Karnataka who work are less likely to attend school than those who do not work.

Kiruma (2010) in a study investigated factors contributing to school dropout in public primary schools in Mukurueini Division, Nyeri District. The researcher used the ex-post facto design to collect the data. The target population included head teachers, teachers and pupils. The study revealed among factors influencing dropout as most pupils being involved in coffee harvesting activities and failing to turn up in school. This study however did not examine ways in which child labour influences participation in school which the current study has addressed.

\subsection{Sand Harvesting and Performance}

According to Akabayashi and Psacharopoulos (1999), the possible importance of reduced learning achievement is well recognized as one of the major harmful effects of child work, and this has been reflected in a number of projects around the world that are designed to mitigate this effect. Although child work has a number of other possible harmful effects, including damage to health and psychological development, particular attention has been paid to its educational impact for two reasons. First, education is seen as fundamental to improving the quality of life in developing countries, by lifting the people who are educated out of poverty and by improving the quality of human resources that are available for national economic development. Second, the impact of child work on education is both easily believable (a child that is working cannot be at school or doing homework at the same time) and has been readily quantifiable from household survey data, at least as measured by school attendance. On the other hand, it might under-estimate the harm of child work, because children that work as well as go to school may find themselves less able to learn, as a result of exhaustion or insufficient time to complete homework. Therefore, there is a strong case for measuring the effects of child work directly on what children are able to do, instead of simply on how long they spend in school (Akabayashi and Psacharopoulos, 1999). 
These problems have led researchers to look for indicators of school achievement that go beyond simple attendance. Thus, Patrinos and Psacharopoulos (1995) found that several factors that contribute to child labour (age, gender, language and number of siblings) reduce school attendance and increase the chances of grade repetition in Paraguay. This was followed, in Patrinos and Psacharopoulos (1997), by the inclusion of a child work variable in equations that were used to estimate the chances of age-grade distortion in Peru. While the estimated coefficient on this variable was positive, indicating that it increased the chances of the child being too old for his/her grade, it was statistically insignificant. However, grade repetition and age-grade distortion are not perfect indicators of learning achievement, as schools may not apply uniform standards in enforcing grade repetition. What is needed is some measure of actual competence. Shafiq, (2007), measurement of the effects of child work on learning achievement can make several contributions. First, it will help in an understanding of the decisions that households make as to whether or not their children should work. Second, it will provide an idea of the educational interventions (perhaps through schooling at more convenient times or less formal education) that might be desirable to mitigate the effects of work on education. Third, it will provide a better idea of one of the benefits of policies and projects to reduce child work, and so lead to the better design of such interventions. This provides strong support for the view that child work harms educational achievement (Delap, 1998).The results show that work has a substantial effect on learning achievement in the key areas of reading and mathematics.

Ng'ang'a (2010) carried out a study on the effects of child labour on girl child educational performance and reconstruction in Kakuzi Division, Thika District. Literature review was done on the various aspects of the child labour and girl child labourers such as their educational rights and children rights, labour laws, past efforts towards improving the girl child educational performances, and reconstruction of child labourers who had previously dropped out of school, etc. The study found out that the educational performance of girls in child labour are poorer than those not in child labour. The participation of girls in child labour, the low educational performance of these girls and the high school dropout rate (42\%) were largely due to poverty. Most of the girl child labourers have not adequately utilized the free primary education. Finally, the study recommends sensitization campaigns, policy formulation, educational awareness of local Provincial Administration on the education of the girl child labourer, and urgent need to curb cases of invisible! Hidden child labour as practiced at the individual households. In addition, financial support to girl child labourers through sponsorships or bursaries, tuition waiver or free secondary education, especially for the poor, and continuing free primary education with introduction of school uniforms is required to control absenteeism (Ng'ang'a, 2010). The study revealed that child labour has negative impact on the educational performance of the girl child, but not much research has been done on the extent of this influence. There was also need to ascertain the impact of girl child labour on their performance in school and the extent of their educational reconstruction, especially after the introduction of the free primary education scheme in Kenya in 2003. This was addressed by the current study.

Kisanya (2009) conducted a study on factors influencing performance in public primary schools in Kangundo District in Eastern Province of Kenya. The target population of the study was all principals, teachers and pupils of public primary schools in Kangundo District and District Education Officer. The study used the systematic sampling design to select the primary schools. Content validity of the research instrument was done by carrying out a pilot study. The split half technique was used to test the reliability of the research instruments. The research established that one of the factors behind poor performance in KCPE was pupils being absent from school to be involved child labour. The study however, did not examine ways in which child labour influences performance which was dealt with in the current study.

\section{Statement of the Problem}

Schools in Kathiani Division have been recording declining education standards in terms of poor performance and low enrolment and retention rates. According to the Kathiani Education Office KCPE Results analysis, the Division recorded a mean mark of 256.5 in 2006 and 2007, which dropped to 255.9 in 2008, then to 234.23 in 2009 and dropped drastically to 205.3 in 2010( Education Office, Kathiani,2011) . Enrolment rates have also been recording significant decline. In 2006, enrolment rates stood at 2,087 then dropped to 2,077 in 2007, then 2,056 in 2008, 2,044 in 2009 and drastically dropped to 1,929 in 2010.

\section{Purpose and Objectives of the Study}

The purpose of this study was to examine the impact of Sand Harvesting on Education of Pupils in Public Primary Schools in Kathiani Division, Kathiani District, Machakos County, Kenya. The study sought to achieve the following objectives:

1. To assess the effects of sand harvesting on pupils access to, retention and dropout rate by gender in primary schools in Kathiani Division, Kathiani District, and Machakos County, Kenya.

2. To examine the effect of sand harvesting on pupils academic performance in national examinations by gender in Kathiani Division Kathiani District, Machakos County, Kenya. 


\section{Theoretical Framework}

The study was premised on the classical liberal theory of equal opportunity advanced by Horace Mann (Coombs, 1988). A theoretical framework brings order, unity and simplicity to what is being investigated (Orodho, 2009). The orientation of this study was on participation rates that should be brought about by equal opportunity in education which is in turn determined by access of and retention in primary education. Classical liberal theory of equal opportunity asserts that each person is born with a given amount of capacity, which to a large extent is inherited and cannot be substantially changed. Thus education system should be designed so as to remove barriers of any nature (socio-economic, gender, geographical and policy) that prevent learners from taking advantage of inborn talents. The theory further observes that the provision of equity to participation in education guarantees that the run is a fair and just one and that achievements in class are determined by inherited capabilities and the will to use them and not by gender and socio-economic status of the student. This theory was found relevant for this study because by removing barriers that hinder participation rates in public primary schools, ideal conditions could be created to implement the vision of equal opportunity where everybody has access to the kind and amount of education that suits his/her inherited capacity. This would in return reduce the incidence of dropouts, absenteeism and repetition which impacts negatively on education (Coombs, 1988).

\section{Research Design and Locale}

\section{Research Methodology}

The study adopted a descriptive survey design. The design was considered appropriate for the study because the survey was concerned with describing, recording, analyzing and reporting conditions that exist or existed (Orodho, 2012). It is an efficient method of collecting descriptive data regarding characteristics of the population, current practices, conditions and preliminary information for generating research questions (Brooks, 2013; Orodho). The study was conducted in Kathiani Division, Kathiani District in Machakos County, Kenya. Kathiani Division was chosen because of the high prevalence of sand harvesting as a means of livelihood.

\section{Target population and Sample Size Determination}

The study targeted two education zones, Kathiani and Mitaboni in Kathiani Division which have 43 primary schools with a total population of 800 class 7 and 8 pupils, 43 head teachers, 200 class teachers, 2 local administration officers and 2 Area Education Officers. A representative sample is one that has at least $10 \%$ of the target population (Kothari, 2005). The researcher therefore used stratified random sampling technique to selected 80 pupils which is $10 \%$ of the total pupil target population of 800 , twenty (20) class teachers which is $50 \%$ and 10 principals. All the 2 local administration officers and 2 Area Education Officers were involved in the study. The entire sampling process yielded a sample size of 104 subjects to participate in the study.

\section{Research Instruments}

The research instruments for the study were questionnaires and interview guides. The questionnaires consisted of, open and closed ended questions. Questionnaires were used because they enable one to collect as much information as possible in a short time. Besides, use of questionnaires enables respondents to feel free to note down their responses without inhibition since they are not being observed. The study also used an observation schedule. The research instruments, particularly the questionnaire were piloted to determine their validity and reliability. There are different types of validity but for this study preferred to focus on the construct validity. Construct validity is perceived as a measure of the degree to which data obtained from an instrument meaningfully and accurately reflects or represents a theoretical concept (Orodho, 2009). For the purposes of this study, content validity of the instruments was established through consultation with seasoned researchers who were members of the academic staff in the Department of Educational Management, Policy and Curriculum Studies, School of Education, Kenyatta University, Kenya. They individually examined the instruments and assessed the relevance of the content to the study. The pilot study helped to improve the face validity, construct validity and content validity of the instruments.

Reliability focuses on the degree to which empirical indicators are consistent across two or more attempts to measure the theoretical concept (Orodho, 2009b). A split half method was used to compute the reliability of the instruments. Koul (1984) as well as Orodho (2012) suggest that the half-split method involving splitting the test items into halves (odd and even items) then calculating the Pearson's Correlation Coefficient ( $r$ ) between the scores of the two halves. The Pearson's Correlation Coefficient (r) formula which was used is:

$$
r=\frac{N \sum x y-\left(\sum x\right)\left(\sum y\right)}{\sqrt{\left[N \sum x^{2}-\left(\sum x\right)^{2}\right]\left[N \sum y^{2}-\left(\sum y\right)^{2}\right]}}
$$

Where: $\mathrm{x}=$ Deviation of the $\mathrm{X}$ measures from the assumed mean and $\mathrm{Y}=$ Deviation of the $\mathrm{Y}$ measures from the assumed mean. The correlation coefficient (r) obtained by the researcher was 0.6998 and was used to 
calculate the whole test reliability using Spearman Brown Prophesy formula $(2 r / 1+r)$. The full reliability of the items was 0.8234 which tends towards +1 , hence the instruments were found to be more reliable and deemed good to use in this study (Orodho, 3009a, 2009b).

\section{Data collection and Analysis}

Data collection was done by use of questionnaires and face to face interviews. Face to face interviews were done using interview guide for the key respondent's especially Education Officers, head teachers and public administrators who did not have ample time to fill in the questionnaire. The researcher administered the questionnaire to the targeted respondents and also conducted face to face interview in person, this gave the interviewer an opportunity to use probing questions where need arose in order to obtain more complete data. Data were analyzed mainly through use of descriptive statistics using the Statistical Package for Social Sciences (SPSS) version 21 and presented in frequency distribution tables, percentages, bar and pie charts and measures of central tendency and variability especially the mean, mode, median and standard deviation. In addition to this, advanced statistical techniques (inferential statistics) were used.

\section{Sand harvesting and school participation}

\section{Findings and Discussion}

The first objective of the study was to investigate the extent to which sand harvesting affects school participation of boys and girls in Kathiani Division. The findings are as discussed in the successive sub-sections.

\section{Dropout cases in schools}

The researcher asked teachers and headteachers in an in-depth interview to state the extent they considered pupils to be dropping out of school in the study locale. The following quote captures the consolidated opinions of teacher and headteacher who participated in the study:

There is little doubt that low access to, and high dropout rate has been a common feature in most primary schools in Kathiani Division. The pupils tend to drop out starting at standard six and reach a peak at standard seven just before getting to their final year of the primary school cycle at standard eight levels. They are attracted by the sand harvesting activities quite prevalent in the study locale. The few who remain are usually demotivated because of the perceived gains of their counterparts in the sand harvesting industry. of pupils, especially the boys( Teachers and Headteachers in Kathiani Division) .

The foregoing revelation is an indication that most public primary schools in Kathiani Division are faced with high rates of school dropout with sand harvesting being cited as the major contributing factor. These findings are in agreement with Baker et al (2001) who observed that a major factor in the non-participation of children in schooling was found to be the need to prioritize educational investment in a few children, with the subsequent earnings of those not enrolled in school contributing to the household finances. But even for those children enrolled in school, their frequent failure to complete primary education was due to an inability of the children successfully to combine income generation, partly to finance their education, with that of school attendance.

\section{The drop-out Trend in the Study Locale}

Head teachers and teachers were asked to give the dropout trends in their schools in the past five years. The findings are as shown in Figure 1.

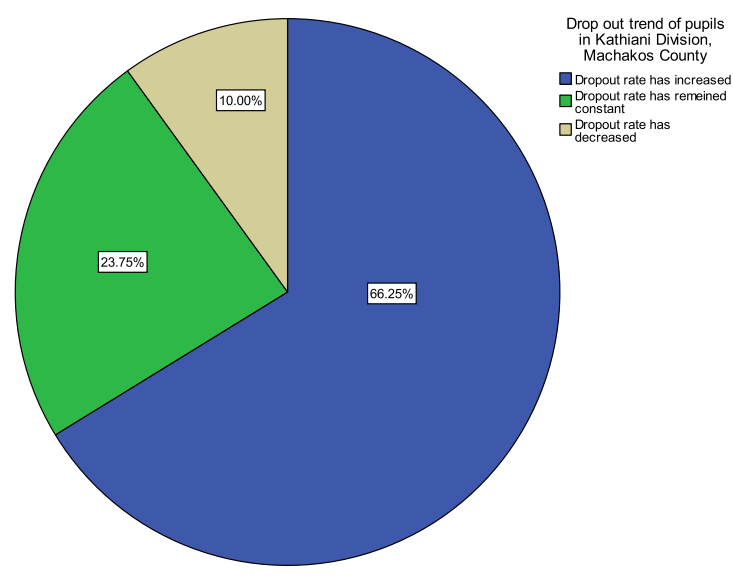


The results in Figure 1 indicate that over two thirds of headteachers ant teachers were of the opinion that the dropout trend has been on the increase over the past five years.

The findings show that majority of head teachers $60 \%$ said that dropout cases have been on an increase in the schools followed by $30.0 \%$ who said they have remained the same while $10.0 \%$ said they have been dropping. The area Education Officer was of the view that dropout incidents have been steadily raising and was a big concern in the division. This confirms the earlier finding that public primary schools in Kathiani Division are experiencing high cases of school dropout as a result of pupils being involved in sand harvesting activities.

\section{Reasons for Dropout according to head teachers and teachers}

The research sought from head teachers and pupils the reasons why pupils are dropping out of school. The findings are as shown on Table 1 .

Table1: Combined ranking of factors causing dropout of pupils in Kathiani Division

\begin{tabular}{|c|c|c|c|c|c|c|}
\hline \multirow[t]{2}{*}{ Causative Factors } & \multicolumn{2}{|c|}{ Headteachers $(\mathrm{N}=10)$} & \multicolumn{2}{|c|}{ Teachers $(\mathrm{N}=10)$} & \multicolumn{2}{|c|}{ Pupils $(\mathrm{N}=80)$} \\
\hline & $\mathrm{N}$ & Rank & $\mathrm{N}$ & Rank & $\mathrm{N}$ & Rank \\
\hline Sand harvesting & 8 & 1 & 7 & 1 & 63 & 1 \\
\hline Indiscipline & 4 & 8 & 5 & 4 & 8 & 9 \\
\hline Teenage Pregnancy & 5 & 6 & 4 & 6 & 19 & 7 \\
\hline Drug Abuse & 6 & 4 & 5 & 4 & 52 & 3 \\
\hline Peer Influence & 7 & 3 & 6 & 2 & 49 & 4 \\
\hline Early marriages & 6 & 4 & 3 & 7 & 21 & 6 \\
\hline Lack of fees( household poverty level) & 8 & 1 & 6 & 2 & 53 & 2 \\
\hline Orphanage/Single parenthood & 3 & 9 & 2 & 8 & 17 & 8 \\
\hline Household Labour & 5 & 6 & 2 & 8 & 48 & 5 \\
\hline Other( value attached to education) & 2 & 10 & 1 & 10 & 12 & 10 \\
\hline
\end{tabular}

The results revealed that there are several factors that combine to cause students to drop out of primary schools in Kathiani Division, Kathiani District, and Machakos District. These factors include sand harvesting, indiscipline among pupils, teenage pregnancy, drug abuse, negative peer influence, early marriages, orphanage resulting to single or no parenthood, lack of fees largely due to household poverty, household labour amongst others. It was found instructive to rank these factors according to number of mentions by headteachers, teachers and pupils to examine in detail the common factors that might be critical in causing dropout in the perspective of the three categories of respondents.

According to the headteachers, the most critical factors causing dropout were sand harvesting and lack of fees due to high household poverty amongst the residents of Kathiani Division. It was pointed out that despite the over involvement of pupils in sand harvesting, the wages paid were not adequate to cater for their fees as well as supplement household income of the poor families where they come from. The third and fourth ranked factors were negative peer influence, early marriages especially among female pupils and drug abuse. It is instructive to note that the sand harvesting lures workers of different ages and backgrounds and the emergence of peer influence, drug abuse and early marriages are vices that could be exacerbated through such social interactions. The other factors mentioned, with some magnitude of influence were orphanage and household labour. It is also important to note that when children lose part of their core parents, they are likely to be misused especially in the household labour.

The teachers' and pupils' views were almost similar to the headteachers perceptions in the sense that they ranked sand harvesting as the most critical factor at position one and lack of fess due to household poverty as well as negative peer influence both at second position. The other two factors that were mentioned by both teachers and pupils were indiscipline and indulgence in drug abuse. This trend is nearly identical to the one given by headteachers which reveals that the major factor causing dropout among the pupils is sand harvesting due to household poverty and this was having negative impact on education in terms of indiscipline and emergence of drug use and abuse.

This is in line with Okojie et al (1996), report that in Nigeria school children get engaged in independent work in order to earn money thus neglecting school. Although not clearly indicated it could be argued that the money is for personal use and the household survival. The findings agree with Kanbargi and Kulkarni (1991) who draw inferences about the effect of work on schooling, concluding that children in Karnataka who work are less likely to attend school than those who do not work. These findings concur with Tungesvik (2000) whose findings indicate that about $61 \%$ of the children who labour are found in Asia, while $32 \%$ live in Africa and 7\% in Latin-America.

\section{Pupils Involvement in Sand Harvesting by Gender}

The head teachers and class teachers were requested to give an estimate of pupils known to be involved in sand harvesting by gender in their respective schools and their responses depicted in Figure 1. The results in 
the figure indicate that although sand harvesting activity attracted pupils of both gender, the males were more involved compared to their female counterparts. Majority of respondents indicated that about three quarters of females who get involved constitute about 1 to 5 of the girls, with the rest attracting between 6-11 girls from their schools. With regard to males, the numbers spread with 20 percent attracting between $1-5$ students, 30 percent attracting between 6-11 boys and 20 percent attracting an average of 20 students or more in the schools sampled.

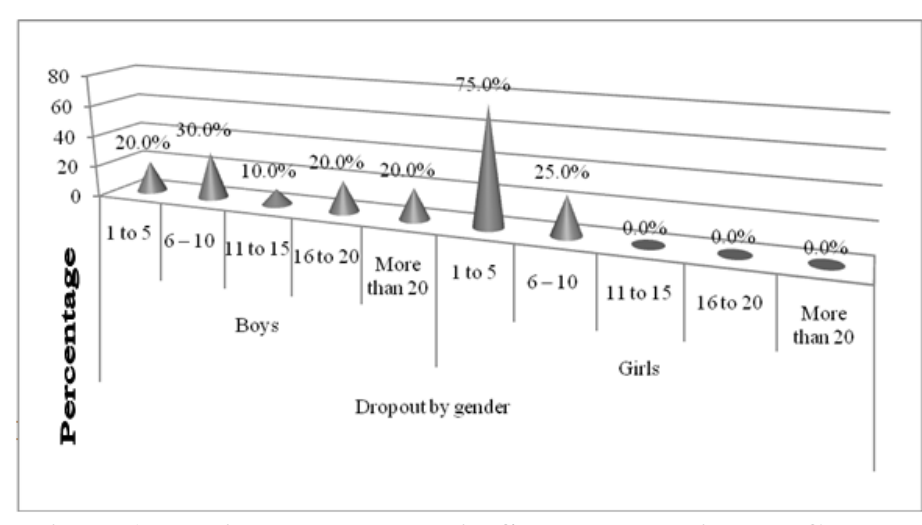

Figure1: Pupils Involvement in Sand Harvesting by Gender

The dominant tone is that more male pupils compared to their female counterparts .The implication of this finding is that boys are the most affected academically by this activity compared to girls. These finding is in tandem with that of Ball and Lamb (2001) that showed that boys are more likely to be 'at risk' of dropping out of school and also demonstrated low academic achievement.

\section{Number of times in a week pupils are involved in sand harvesting}

From the findings, a higher number of pupil that is $29(36.6 \%)$ said they are involved in sand harvesting twice a week followed by 22 pupils $(27.2 \%)$ who said they are involved once a week then 14 pupils $(18.1 \%)$ who said they are involved on daily basis, 10 pupils(12.1\%) are involved thrice a week. and lastly 5 pupils $(6.0 \%$ ) said they are involved four times a week .The Area Education Officer observed that most pupils have had to forfeit attending lessons to participate in sand harvesting. The results show that pupils in public primary schools in Kathiani Division are spending a substantial amount of school time in sand harvesting thus negatively affecting their school attendance.

\section{Time when Sand Harvesting Done}

\section{Factors contributing to pupils Dismal Academic Performance}

The pupils who reported to be involved in sand harvesting provided information carried in Figure 2 regarding the time when they get involved in the activity. The results portrayed in Figure 2 indicate that majority of respondents, constituting nearly one third of the total number of students who get involved in sand harvesting conduct their activities either in the evenings or at night

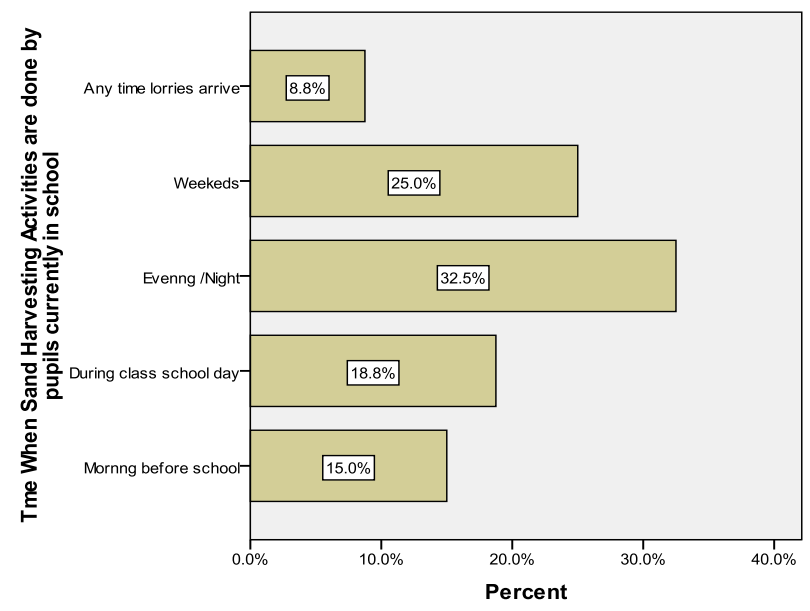

Figure 2: Time when pupils are involved in sand harvesting 
It was also evident that a good proportion of the pupils, constituting over 25 percent, conduct the sand trade activities over the weekends. At the same time, the percentage of students who get involved in these activities in the morning before school is also fairly large as it stands at about 15 percent. The overall picture is that nearly three quarters of the total number of pupils sampled who get involved in sand harvesting activities do so either early in morning before school, in the evening, at night or over the weekends. As such, the school authorities are unable to detect the exact number of pupils who get distracted by the time consuming and energy depleting activities since it is done outside school hours.

The implication is that the pupils get to school when they are exhausted and less prepared to cope with academic activities which also require a lot of mental energy and concentration. The headteachers and teachers interviewed were in agreement that

The sand harvesting activities take a lot of school time needed to do the assignments at home. The activities distract their attention from the core business of education as they attempt to assist their parents cope with the high level of poverty at the household level. The pupils have no option since this is almost a survival technique at the expense of schooling. The end result is the deteriorating academic performance as noted in the dismal performance of pupils from Kathiani Division, Machakos County in national examinations.( In-depth interviews with Headteacher X and Teacher Y, Kathiani Division, Machakos County, 2013).

These findings are in agreement with Baker et al (2001) who observed that a major factor in the nonparticipation of children in schooling was found to be the need to prioritize educational investment in a few children, with the subsequent earnings of those not enrolled in school contributing to the household finances. But even for those children enrolled in school, their frequent failure to complete primary education was due to an inability of the children successfully to combine income generation, partly to finance their education, with that of school attendance.

\section{Other Sand Harvesting Related Factors Contributing to Dismal Performance}

According to the headteachers interviewed, they tended to agree on other factors contributing to pupils' poor academic performance in their respective schools when they averred that:

The other factors influencing performance in their schools a part from sand harvesting drug use and abuse, indiscipline as well as absenteeism due to prolonged interactions with other pupils and adults who are also involved in the sand harvesting activities.

The Quality Assurance and Standards Officer (QUASO) in the study locale also noted the rampart involvement of children of school going age in this sand harvesting industry. In fact, the education officer and the local administration officer revealed that:

...... on a number of occasions their officers have arrested some pupils who were harvesting sand at the time they should have been in school. They lamented that quite a number of pupils are involved in sad harvesting during school hours which negatively affects their participation in school in Kathiani Division as well as other vices most of which are related to sand harvesting such as drug abuse and absenteeism..

The findings are an indication that pupils involved in sand harvesting are recording poor results in examinations owing to missing school and other vices related to sand harvesting.

These findings are an indication that sand harvesting is contributing to a large extent to poor performance in public primary schools. This concurs with Akabayashi and Psacharopoulos (1999) who assert that the possible importance of reduced learning achievement is well recognized as one of the major harmful effects of child work. According to Akabayashi and Psacharopoulos (1999) however, it could also be caused by those children who work being innately less interested in academic achievement. Kisanya (2009) in a study on factors influencing performance in public primary schools in Kangundo District in Eastern Province of Kenya established that one of the factors behind poor performance in KCPE was pupils being absent from school.

\section{Conclusion and recommendation}

The gist of this study was to investigate the impact of sand harvesting on education of pupils in public primary schools in Kathiani Division, Machakos County, Kenya. The study revealed that sand harvesting is having a substantial negative impact on participation of pupils in education as a number of pupils have dropped out of school to join in sand harvesting while quite a number of them are involved in harvesting either during morning hours before school, evening, at night, over the weekends or during school hours leading to poor attendance. The study also revealed that sand harvesting has led to poor performance as pupils involved in the exercise are recording low grades. The study therefore concludes that although sand harvesting is an essential activity given the poor economic status of the pupils' parents, it has negative impact on school attendance and overall academic performance of the pupils. 
In the light of the findings and conclusions of the study, the following recommendations were deemed important for the enhancement of school attendance and subsequent academic performance:

1. The Government of Kenya, through the provincial administration and County Government structures, Ministry of Education Officials and other legal mechanisms should regulate sand harvesting activities through constant monitoring to ensure that under-age children are not used as labourers to enhance participation in schools.

2. The government of Kenya and other corporate sponsors should provide bursaries to needy pupils to minimize cases of pupils having to engage in sand harvesting to raise money for their education. This will promote participation rates as pupils will not have to be involved in sand harvesting to get funds to finance their education.

\section{Reference}

[1]. Admassie A (2002). Explaining the High Incidence of Child Labor in Sub-Saharan Africa. Afr. Dev. Rev., 14(2): 251-275.

[2]. Akabayashi, H. and G. Psacharopoulos, (1999). "The trade-off between child labour and human capital formation: A Tanzanian case study", Journal of Development Studies, Vol. 35, No. 5, pp.120-140.

[3]. Amma, H, Baghdellah, J, Kiondo, E, Madhi, M, Mwandayi, E; and Soko, P (2000). The Nature and Extent of Child Labour in Tanzania: A Baseline Study, ILO-IPEC, March.

[4]. Baker, R (with Hinton, R and Crawford, S) (2001). The Sexual Exploitation of Working Children: Guidelines for Action to Eliminate the Worst Forms of Child Labour. London: DFID Social Development.

[5]. Bass LE (2004). Child Labor in sub-Saharan Africa. Boulder: Lynne Rienner Publishers.

[6]. Carron, G and Chau, T N (1996). The Quality of Primary Schools in Different Development Contexts, UNESCO Publishing: International Institute for Educational Planning.

[7]. Coombs, P. (1988). The world Crisis in Education. New York: Oxford University press.

[8]. Edmonds E, Turk C (2003). Child labor in Transition in Vietnam. Policy Research Paper 2774. World Bank Dev. Res. Group, Washington DC.

[9]. EFA Assessment Report(2000). Education for All meeting our collective commitments. Text adopted by the World Education Forum. Senegal 26-28 April.

[10]. Grootaert C, Patrinos HA (1999). The Policy Analysis of Child Labor: A Comparative Study. New York: St. Martin's Press.

[11]. Grootaert, C. and H.A. Patrinos, (1998). The policy analysis of child labor: a comparative study, St. Martin's Press.

[12]. ILO - IPEC, (2000). Accelerating Action against child Labor (U.K.).

[13]. Kanbargi, R. and P.M. Kulkarni, (1991). "Child work, schooling and fertility in rural Karnataka, India" in R. Kanbargi (ed.), Child labour in the Indian Subcontinent, Sage.

[14]. Kaunga J (2008) Review of existing child labour Initiatives, Experiences and Lessons Learned and Strategies for further Interventions in Selected Pastoralists Communities in Kenya-ILO project to promote ILO Policy on Indigenous and Tribal peoples Rights.(PRO169).

[15]. Kiruma, J. W. (2010). A study investigated factors contributing to drop out in public primary schools in Mukurueni Division, Nyeri District. Unpublished M. Ed Project, University of Nairobi.

[16]. Kisanya, L. L. (2009). Factors influencing performance in public primary schools in in Kangundo District in Eastern Province of Kenya.Unpublished M. Ed Project, University of Nairobi.

[17]. Kothari, C.R. (2005). Research Methodology- Methods and Techniques. New Delhi Willey Eastern Limited.

[18]. Koul, R. (1987). Educational research competencies for analysis and application. Ohio: Merill Publishing company.

[19]. Lanjouw, P and Feder, G (2002). Rural Non-formal Activities and Rural Development: from Experience to Towards Strategy (Working Paper) Washington DC: The World Bank.

[20]. Masudi, A, Ishumi, A, Mbeo, F and Sambo, W (2001). The Worst Forms of Child Labour (WFCL): an Investigation of Tobacco Farms and Plantations in Tanzania, Department of Educational Foundations, University of Dar es Salaam, ILO.

[21]. Ng'ang'a, D. (2009). A study on the effects of child labour on girl child educational performance and reconstruction in Kakuzi Division, Thika District. . Unpublished M. Ed Project, University of Nairobi.

[22]. Nielsen, H.S., 1998, "Child labour and school attendance: two joint decisions", Working Paper 98-15, Centre for Labour Market and Social Research, University of Aarhus and the Aarhus School of Business.

[23]. Okojie, C E E, O Chiegwe, \& E Okpokunu (1996). Gender Gap in Access to Education in Nigeria: Pilot Study, Abridged Research Report No 12, Research Priorities for the Education of Girls and Women in Africa.

[24]. Orodho A.J(2009a) Elements of Education and Social Science Research Methods. Kanezja Enterprises.

[25]. Orodho A.J(2009b) Techniques of Data Analysis using Statistical Package for Social Sciences (SPSS) Computer package . Kanezja Enterprises.

[26]. Orodho A.J(2012) Techniques of writing research proposals and reports in Education and Social Sciences . Kanezja Enterprises.

[27]. Patrinos H, Psacharopoulos G (1997). Family Size, Schooling, and Child Labor in Peru - An Empirical Analysis. J. Popul. Econ., 10: $387-405$.

[28]. Shafiq, M.N., 2007. Household schooling and child labour decisions in rural Bangladesh. Journal of Asian Economics, forthcoming.

[29]. Tungesvik, R (2000). Education Child Labour-an initial mapping of the field, LINS: Oslo College/Hogskolen i Oslo UNO (1989).

[30]. UNICEF (1997),Situation Analysis of children and women in Kenya.

[31]. UNICEF (2007). The State of the World's Children, New York: UNICEF.

[32]. World Bank, 2007. Cambodia Sharing Growth, Equity and Development. Report prepared for the Cambodia Development Cooperation Forum.' 